\title{
High-efficiency biolistic co-transformation and regeneration of 'Chardonnay' (Vitis vinifera L.) containing npt-II and antimicrobial peptide genes
}

Received: 13 April 2003 / Revised: 7 June 2003 / Accepted: 10 June 2003 / Published online: 8 August 2003 (C) Springer-Verlag 2003

\begin{abstract}
A reliable and efficient system for transformation and regeneration of 'Chardonnay' (Vitis vinifera L.) plants via microprojectile bombardment was developed. Improvements over the previous biolistic transformation system included: (1) the use of gold particles for bombardment; (2) step-wise selection at 10 then $15 \mathrm{mg} / \mathrm{l}$ kanamycin; and (3) embryo induction at $27^{\circ} \mathrm{C}$. Embryogenic cell cultures were either bombarded with pBI426, which contains the reporter gene gus (uidA) coding for $\beta$-glucuronidase (GUS), or were co-bombarded with pSAN237 carrying the npt-II (neomycin phosphotransferase II) selectable marker gene, and a second plasmid with an antimicrobial peptide gene. A large number of transient $(7,883 \pm 1,928)$ and stable $(46 \pm 32)$ blue spots per plate at 2 and 95 days after bombardment, respectively, were obtained according to GUS expression analyses. A total of 447 putative transgenic embryos was harvested from 84 bombarded plates. From these embryos, 242 (54\%) were regenerated into plants within the first year of the experiment. Southern blot analyses confirmed integration of the transgenes into the grape genome. Cotransformation was tested with four separate antimicrobial constructs. The co-transformation frequency of unlinked genes was $48 \%$ as measured by polymerase chain reaction (PCR), and $56 \%$ as estimated by dot blot hybridization. Expression of the gus gene, and PCR and Southern blot analyses of $n p t-I I$ and antimicrobial genes from regenerated plants document stable transformation of 'Chardonnay' and establish the parameters for highly-efficient biolistic transformation in $V$. vinifera.
\end{abstract}

Communicated by E.D. Earle

J. R. Vidal · J. R. Kikkert · P. G. Wallace · B. I. Reisch $(-)$

Department of Horticultural Sciences,

New York State Agricultural Experiment Station,

Cornell University,

Geneva, NY 14456, USA

e-mail: bir1@cornell.edu

Tel.: +1-315-7872239

Fax: +1-315-7872216
Keywords Antimicrobial peptide - Biolistics . Co-transformation · Regeneration · Vitis vinifera L.

Abbreviations AMP: Antimicrobial peptide - $D B H$ : Dot blot hybridization - GM+NOA: Glycerol and maltose liquid medium with $\beta$-naphthoxyacetic acid $\cdot$ gus: $\beta$-Glucuronidase gene - GUS: $\beta$-Glucuronidase . $\mathrm{Km}$ : Kanamycin $\cdot \mathrm{Km}^{R}$ : Kanamycin resistant . mag2: Magainin-2 $\cdot$ MS: Murashige and Skoog medium . MS/2: Half-strength Murashige and Skoog medium . nos: Nopaline synthase - npt-II: Neomycin phosphotransferase II gene - PCR: Polymerase chain reaction PGL: Peptidyl-glycine-leucine - Pubq3: Arabidopsis ubiquitin-3 promoter - Pubq10-L: Arabidopsis ubiquitin-10L promoter $\cdot$ Pubq11: Arabidopsis ubiquitin-11 promoter $\cdot S P$ : Signal peptide .

Tnos: Nopaline synthase terminator -WPM: Woody plant medium

\section{Introduction}

Genetic transformation of elite grapevine cultivars (Vitis vinifera L.) is a potentially important tool to improve traits such as disease resistance without altering cultivar identity (Colova-Tsolova et al. 2001; Kikkert et al. 2001). Successful application of genetic engineering technology to grapevine requires efficient transformation and regeneration methods. A long (5-10 year) period is required to evaluate plant performance in the field. Thus, it is desirable to produce a large pool of transgenic lines to enable the selection of plants with stable transgene expression and a normal phenotype. Transformation of grapevine has been reported using the Agrobacteriummediated system (Nakano et al. 1994; Mauro et al. 1995; Perl et al. 1996; Scorza et al. 1996; Yamamoto et al. 2000; Iocco et al. 2001) and also by direct DNA delivery via biolistics (Kikkert et al. 1996). In both systems, embryogenic cultures were used for transformation. Grapevines are difficult to transform (Kikkert et al. 2001) and very sensitive to kanamycin (Km) (Colby and 
Meredith 1990), the most commonly used selection antibiotic, which has an inhibitory effect on shoot emergence. Even in recent reports, the development of transgenic shoots from embryos is often a limiting step (Iocco et al. 2001). This may be due to a hypersensitivitylike reaction of grapevine to A. tumefaciens (Perl et al. 1996) in combination with antibiotics used to kill Agrobacterium and the high levels of $\mathrm{Km}(50-100 \mathrm{mg} / \mathrm{l})$ often used for selection. To improve the Agrobacterium system, researchers have focused on varying the Agrobacterium strains, selection media and embryo induction media (Torregrosa et al. 2002a).

The biolistic device is an alternate method for transformation, and obviates some of the problems associated with the use of Agrobacterium in grapevines. As in any transformation system, the parameters for gene insertion and plant regeneration must be optimized. For biolistics, this includes both physical and biological parameters (Nandadeva et al. 1999). Hébert et al. (1993) studied the effects of tungsten particle size, helium pressure, and target distance on transient and long-term $\beta$-glucuronidase (GUS) expression in embryogenic cultures of the grapevine interspecific hybrid cv. Chancellor (Vitis L.). Kikkert et al. (1996) further improved cell culture and selection parameters, and transgenic 'Chancellor' plants were obtained. Kikkert et al. (2000) employed the same procedure to produce transgenic 'Chardonnay' and 'Merlot' vines using 25-50 mg/l Km for selection. Other groups have reported good rates of transient GUS expression following biolistic transformation, but either non-regenerable cells were used (Torregrosa et al. 2002b) or difficulties in the selection procedure prohibited regeneration of transgenic plants (Franks et al. 1998). Clearly, transformation by either Agrobacterium or biolistics is not routine for most grapevine genotypes.

Foreign genes can be delivered into genomic DNA either linked into the same construct or carried on separate plasmids (co-transformation). The frequency of integration for linked genes on the same plasmid is higher than for unlinked genes on separate plasmids (Aragao et al. 1996). Co-transformation with two independent DNA constructs was initially used for the genetic separation of the selectable marker in subsequent generations (Komari et al. 1996). In addition, co-transformation obviates the need to construct new plasmids combining desired genes in multiple-gene strategies. Co-transformation studies from regenerated plants have never been reported in grapevine. We studied the efficiency of biolistic cotransformation in grapevine for multiple-gene transformation purposes using the neomycin phosphotransferase II gene (npt-II) and antimicrobial genes [magainin and peptidyl-glycine-leucine (PGL) classes of antimicrobial peptide (AMP) genes (Maloy and Kari 1995)] driven by Arabidopsis ubiquitin promoters (Norris et al. 1993).

Our long-term goal is to develop transgenic diseaseresistant grapevines. To facilitate this goal, we report here an improved method resulting in reliable biolistic cotransformation of embryogenic cell suspensions coupled with high-efficiency regeneration of a large number of plants.

\section{Materials and methods}

Plant material

Embryogenic cell cultures of 'Chardonnay' clone 95 ( $V$. vinifera L.) were obtained from anthers or ovaries as described by Kikkert et al. (1997). Cell suspensions were developed in $250 \mathrm{ml}$ Erlenmeyer flasks with $50 \mathrm{ml}$ glycerol and maltose liquid medium with $\beta$-naphthoxyacetic acid (GM+NOA) [Murashige and Skoog (MS) salts and vitamins with $1.8 \%(\mathrm{w} / \mathrm{v})$ maltose, $0.37 \%(\mathrm{v} / \mathrm{v})$ glycerol, and 5.0 $\mu M \beta$-naphthoxyacetic acid] (Mauro et al. 1995), adjusted to $\mathrm{pH} 5.8$ before autoclaving, and maintained on a gyratory shaker at $125 \mathrm{rpm}$ and $23 \pm 1^{\circ} \mathrm{C}$ in the dark. Suspension cultures were subcultured to fresh GM+NOA every week. After 4 days in fresh medium, cell suspensions were filtered through a double mesh (pore size $1.1 \mathrm{~mm}^{2}$ ) and cell density for bombardment was adjusted to $0.2 \mathrm{ml}$ per $10 \mathrm{ml}$ settled cell volume, as described by Kikkert (1998). Target cells ( $5 \mathrm{ml})$ were spread as a single layer onto a disk of Whatman No. 2 filter paper $(8 \mathrm{~cm}$ in diameter) pre-dampened with $1 \mathrm{ml} \mathrm{GM+NOA}$. Filter papers were then placed on hormonefree half-strength Murashige and Skoog (1962) (MS/2) bombardment medium with $0.125 M$ mannitol, $0.125 M$ sorbitol, $30 \mathrm{~g} / \mathrm{l}$ sucrose and $2.5 \mathrm{~g} / \mathrm{l}$ Phytagel (Sigma) as described by Hébert et al. (1993).

\section{Constructs}

Six circular plasmids were used for transformation experiments (Fig. 1). pSAN237 (approx $4.6 \mathrm{~kb}$ ) harbors the $n p t-I I$ gene under the control of the Arabidopsis ubiquitin-11 promoter (Pubq11) and the nopaline synthase (nos) terminator (Tnos) from Agrobacterium tumefaciens T-DNA. Co-transformation was carried out with pSAN237 and a second plasmid with an AMP gene controlled by the Arabidopsis ubiquitin-3 promoter (Pubq3) and Tnos. Cotransformation was tested with four separate AMP constructs:

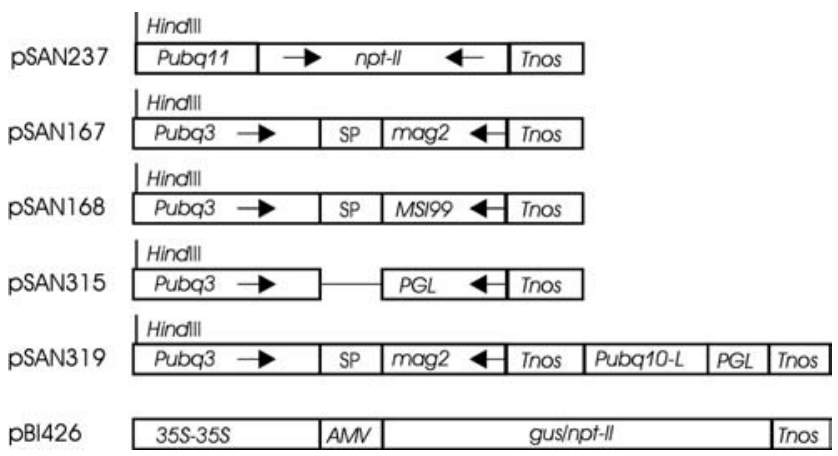

Fig. 1 Schematic representation of the gene constructs used for bombardment. Diagrams of the cassettes are not to scale. Elements of the cassettes are as follows: Pubq3, Pubq10-L and Pubq11 are Arabidopsis thaliana ubiquitin promoters; $35 S-35 S$ is a double $35 \mathrm{~S}$ cauliflower mosaic virus promoter; Tnos is the Agrobacterium tumefaciens T-DNA nopaline synthase terminator; $n p t-I I$ (792-bp) is the Escherichia coli neomycin phosphotransferase II gene; SP (48-bp) is a signal peptide from pea vicilin protein; mag2 (72-bp) is a magainin class gene and $P G L(63-b p)$ is a peptidyl-glycineleucine class gene, both from Xenopus laevis; MSI99 (69-bp) is a synthetic magainin class gene; $A M V$ (44-bp) is a leader sequence of alfalfa mosaic virus and gus/npt-II (2,800-bp) is a gene fusion between the gene for $\beta$-glucuronidase (gus) and $n p t-I I$. Arrows on the cassettes indicate the primer annealing sites 
pSAN167 (approx $4.6 \mathrm{~kb}$ ) harbors the natural lytic peptide gene magainin-2 (mag2) fused in frame to a signal peptide (SP) from pea vicilin protein for secretion of the AMP out of the cell cytosol; pSAN168 (approx $4.6 \mathrm{~kb}$ ) harbors the synthetic lytic peptide gene MSI99 ligated to the SP; pSAN315 (approx $4.3 \mathrm{~kb}$ ) harbors the synthetic lytic peptide gene $P G L$; and pSAN319 (approx $5.9 \mathrm{~kb}$ ) harbors a double cassette containing the SP plus the mag2 gene driven by Pubq3, and the PGL gene driven by the Arabidopsis ubiquitin-10-L promoter (Pubq10-L). All pSAN constructs are pUC19-based plasmids and were obtained from Sanford Scientific and FMS Foundation, Waterloo, N.Y. (unpublished vectors). pBI426 (approx $5.5 \mathrm{~kb}$ ), containing a gus/npt-II gene fusion under the control of a double $35 \mathrm{~S}$ cauliflower mosaic virus promoter, the alfalfa mosaic virus leader sequence and the nos polyadenylation sequence, was used for expression studies on the $\beta$-glucuronidase gene (gus) (Hébert et al. 1993). Plasmid DNA for transformation was amplified in Escherichia coli strain DH10b, isolated and purified using a plasmid purification kit (Qiagen), and resuspended in Tris-EDTA buffer (1.0 $\mathrm{m} M$ Tris and $0.1 \mathrm{~m} M \mathrm{Na}_{2}$ EDTA, pH 8.0). DNA was quantified with a fluorometer and concentration was adjusted to $1.0 \mu \mathrm{g} / \mu \mathrm{l}$.

\section{Bombardment conditions}

Tungsten (1.0- $\mu$ m diameter, M10, Sylvania GTE Products, Towanda, Pa., USA) and gold (0.75- $\mu$ m diameter, Analytical Scientific Instruments, El Sobrado, Calif., USA) particles were used as microcarriers for bombardment. The Sanford method for coating DNA onto particles was followed (Sanford et al. 1993). To improve DNA delivery into cells, particles were heated at $180^{\circ} \mathrm{C}$ for $12 \mathrm{~h}$ before coating with DNA, and isopropanol was used during all steps of coating as suggested by Sawant et al. (2000). Plasmid DNA $(5.0 \mu \mathrm{g})$ was complexed with particles by $\mathrm{CaCl}_{2} /$ spermidine precipitation, and loaded onto macrocarrier disks, both as described by Kikkert (1993). For co-bombardment, gold particles were coated with a mixture of $2.5 \mu \mathrm{g}$ plasmid DNA per construct. Cell suspensions $(5.0 \mathrm{ml})$ were prepared for bombardment as described above. The biolistic device used was the prototype of the commercially available PDS-1000/He of BioRad. The biolistic parameters were as described by Kikkert et al. (1996).

\section{Experimental design}

Two separate experiments were performed with different cell suspensions and plasmid DNA (Table 2). In the first experiment (E1), plates containing cell suspension were co-bombarded with pSAN237 (npt-II) and a second plasmid, either pSAN167 (mag2) or pSAN168 (MSI99). In the second experiment (E2), cell suspensions were co-bombarded with pSAN237 (npt-II) plus either pSAN315 $(P G L)$ or pSAN319 (mag2 $+P G L)$. In total, 18 plates (three replicates) were co-bombarded for each plasmid combination. In addition, for each experiment, six plates were bombarded with pSAN237 (npt-II), 12 plates with pBI426 (gus/npt-II) and, as a negative control, six plates were not bombarded.

\section{Post-bombardment cell handling}

All bombarded and non-bombarded cells were incubated in the dark at $23 \pm 1^{\circ} \mathrm{C}$ for 2 days to allow cell repair and DNA integration. After a period of $16 \mathrm{~h}$ following the bombardment, the osmotic pressure of the medium was reduced gradually as described by Kikkert et al. (1996). Two days after bombardment, all cells were placed on hormone-free MS/2 selection medium, containing $10 \mathrm{mg} /$ $1 \mathrm{Km}, 30 \mathrm{~g} / \mathrm{l}$ sucrose, $3.0 \mathrm{~g} / \mathrm{l}$ activated charcoal and $7.0 \mathrm{~g} / \mathrm{l}$ Bactoagar. Four weeks later, Km was increased to $15 \mathrm{mg} / \mathrm{l}$. Cells on the original filter paper support were transferred to fresh selective medium every 4 weeks. During the selection period, Petri plates were wrapped with Parafilm and incubated in the dark in a growth chamber at $27 \pm 0.1^{\circ} \mathrm{C}$ for embryo induction (Harst et al. 2000).
Embryo germination and plant regeneration

Individual embryos with a radicle $1-2 \mathrm{~cm}$ long were harvested from $\mathrm{Km}$ medium and placed directly on germination medium in Petri plates. Germination medium (MS/2, $\mathrm{pH} 5.8)$ was $\mathrm{Km}-$ and hormone-free and contained $3.0 \mathrm{~g} / \mathrm{l}$ activated charcoal and $2.5 \mathrm{~g} / \mathrm{l}$ Phytagel. Embryos were incubated either at $4^{\circ} \mathrm{C}$ in the dark for 2 weeks for chilling treatment (Martinelli and Mandolino 1994) and then incubated at $23 \pm 1^{\circ} \mathrm{C}$ with low light intensity $\left(10 \mu \mathrm{E} \mathrm{m}^{-2} \mathrm{~s}^{-1}\right)$, under a $14 \mathrm{~h}$ light $/ 10 \mathrm{~h}$ dark photoperiod, for 2 additional weeks, or incubated at $23 \pm 1^{\circ} \mathrm{C}$ with low light intensity for 4 weeks. After this initial treatment, embryos were transferred every 4 weeks to fresh germination medium in baby-food jars, which were wrapped with Venting tape (3M Corporation) and incubated at $23 \pm 1^{\circ} \mathrm{C}$ with increased light intensity $\left(50 \mu \mathrm{E} \mathrm{m}^{-2} \mathrm{~s}^{-1}\right)$, under a $14 \mathrm{~h}$ light $/ 10 \mathrm{~h}$ dark photoperiod. Germinated embryos with elongated roots and open green cotyledons were transferred to baby-food jars containing hormone-free woody plant medium (WPM) (Lloyd and McCown 1980), pH 5.8, with $20 \mathrm{~g} / \mathrm{l}$ sucrose and $2.5 \mathrm{~g} / \mathrm{l}$ Phytagel. Embryos were incubated at $23 \pm 1^{\circ} \mathrm{C}$ for root elongation and shoot formation. Regenerated plants were maintained on WPM in Magenta boxes at $23 \pm 1^{\circ} \mathrm{C}$ for multiplication and transferred to fresh medium every 6-8 weeks.

\section{Analysis of transformants}

Transient and long-term GUS expression were assayed among pBI426-bombarded cells. The histochemical assay was performed at four different times on six randomly chosen bombarded plates. Filter papers with cells were transferred to Petri plates, and $600 \mu \mathrm{l}$ 5-bromo 3-chloro 3-indolyl $\beta$-D-glucuronic acid solution (McCabe et al. 1988) was placed on top of the cells. Plates were incubated at $37^{\circ} \mathrm{C}$ overnight in the dark. GUS-positive cells turned blue. The number of blue spots per plate was counted with a stereo dissecting scope at $20 \times$. Each cluster of blue cells was counted as a single spot.

Genomic DNA was isolated from in vitro plant leaves and initially screened by polymerase chain reaction (PCR) and dot blot hybridization (DBH) for positive signals of exogenous genes. Later, Southern blot analyses were performed to confirm integration and determine copy number. DNA extraction was carried out as described by Lodhi et al. (1994). The PCR reaction $(25 \mu \mathrm{l})$ contained 5.0 ng genomic DNA, 1×reaction buffer, $100 \mu M$ deoxynucleoside triphosphates, $0.2 \mu M$ each primer and $1.0 \mathrm{U}$ Taq DNA polymerase (Sigma). Multiplex PCR was also used to screen for both transgenes simultaneously. The primers used for amplification of a 750-bp fragment of the npt-II gene were $5^{\prime}$ CAAGATGGATTGCACGCAGG- $3^{\prime}$ and $5^{\prime}$-TTGAGCAGTTCTTCCGCTATC-3'. For the AMP constructs, to amplify a fragment of approx $400 \mathrm{bp}$, the forward primer (5'-CACGTATCATATGATTCCTTCC- $3^{\prime}$ ) was designed to anneal within Pubq3 (accession L05363, National Center for Biotechnology Information) beginning at nucleotide 1,106 , and the reverse primer at the $3^{\prime}$ end of each AMP gene (5'-TTAACTGTTCATGATCTCACC- $3^{\prime}$ for mag2; 5'-GAGCTCGTTAGGAGTTCAGG-3' for MSI99; and 5' TTAAAGGGCCTTCAATGCCAC- $3^{\prime}$ for $P G L$ ) (Fig. 1). The optimal annealing temperature for each primer pair was determined using the gradient function of a Mastercycler thermocycler (Eppendorf). PCR amplification was carried out in a PTC 100 thermocycler (MJ Research), which was programmed for one initial step of $2 \mathrm{~min}$ at $95^{\circ} \mathrm{C}$, followed by 35 cycles of $30 \mathrm{~s}$ at $94^{\circ} \mathrm{C}, 30 \mathrm{~s}$ at the optimal annealing temperature and $1 \mathrm{~min}$ at $72^{\circ} \mathrm{C}$, and then 5 min at $72^{\circ} \mathrm{C}$. PCR products were separated by electrophoresis in $1 \%(\mathrm{w} / \mathrm{v})$ agarose gels containing ethidium bromide. Profiles were recorded with a Gel Doc 2000 camera and the Quantity One program (BioRad).

Probes for hybridization were made from PCR fragments amplified from the original constructs, then gel purified and labeled using the DIG DNA labeling kit (Roche) as described by Vidal et al. (2000). For DBH analysis, genomic DNA $(3-5 \mu \mathrm{g})$ was loaded in the wells of a $0.7 \%(\mathrm{w} / \mathrm{v})$ agarose gel and run for $40 \mathrm{~min}$ at $50 \mathrm{~V}$. 
For Southern blot analysis, genomic DNA (5 $\mu \mathrm{g})$ was digested to completion with HindIII (Promega) and then DNA fragments were separated by electrophoresis in $0.8 \%$ agarose gel for $4 \mathrm{~h}$ at $30 \mathrm{~V}$. For both DBH and Southern blot analyses, DNA was transferred overnight to a MSI-neutral nylon membrane (MagnaGraph) using alkaline capillary transfer. The DNA was then fixed to the membrane by baking at $120^{\circ} \mathrm{C}$ for $30 \mathrm{~min}$. Hybridization and chemiluminescence detection was performed as described by Vidal et al. (2000). X-ray films (BioMax light, Kodak) were exposed to blots for a period of $1-10 \mathrm{~h}$.

\section{Results}

\section{Transient and long-term GUS expression}

In a preliminary experiment, the effect of tungsten and gold microcarriers on transient expression of the gus gene in grape cells was compared. An embryogenic 'Chardonnay' cell suspension that had been maintained in our lab for 2 years was bombarded with pBI426 coated

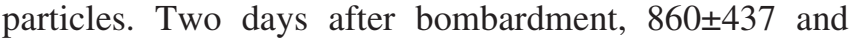
$1,317 \pm 346$ blue spots per plate were obtained for tungsten and gold particles, respectively. The difference was statistically significant as determined by a $t$-test $(P \leq 0.01)$. Gold particles were used for all subsequent experiments. To decrease the chance of producing somaclonal variants from tissue culture and to have more competent cells for transformation, a fresh embryogenic cell suspension was initiated for subsequent experiments.

The evolution of GUS expression in the present study was checked at four different times on three randomly chosen pBI426-bombarded plates from each experiment (Table 1). Transient GUS expression 2 days after bombardment was very high in both experiments with an average of $7,883 \pm 1,928$ blue spots per plate. Distribution of the blue spots was uniform across the $8-\mathrm{cm}$ diameter support of the targeted cells, with slightly more blue spots near the border of the filter paper. Long-term GUS expression decreased over time when the bombarded cells were grown on selective medium. The reduction of blue spots was highly significant as determined by a $t$-test $(\alpha=0.001)$. Ninety-five days after bombardment, $46 \pm 32$ blue spots per plate were obtained and considered to be indicative of stable transformation. At this time, most of the GUS-positive spots appeared in undifferentiated tissues and only a few included embryos.
Embryo germination and plant regeneration

Embryo development was followed for 6 months after bombardment and plant regeneration continued for 6 additional months (Table 2). Embryos developed within the 1st month on all non-bombarded plates grown on $\mathrm{Km}$-free medium, and embryos continued to appear until the 6th month at which time the surface of the filter paper was completely saturated, suggesting that the cell suspensions were at an optimal stage for embryogenesis. No embryos were observed in non-bombarded cells grown on $\mathrm{Km}$ selective medium until 6 months after bombardment, indicating the selection pressure was operating well.

The first kanamycin-resistant $\left(\mathrm{Km}^{\mathrm{R}}\right)$ embryos were obtained on bombarded plates 6-8 weeks after bombardment. The emergence of embryos, however, differed between E1 and E2. The cell clusters in E2 (smaller target clusters) were more finely divided and spread more evenly on the filter paper than the clusters used in E1 (larger target clusters). The embryos in E1 (195) emerged mainly after the 2nd month on selective medium, and decreased in production after the 4th month. The embryos in E2 (252) arose rapidly after the 3rd month on selective medium and decreased during the 6th month (data not shown). Embryos were harvested from 78 of the 84 bombarded plates (Table 2). Embryos arose from separate places on the filter paper and were treated as independent transformation events.

A total of $447 \mathrm{Km}^{\mathrm{R}}$ embryos were harvested in the 5 months following bombardment (Table 2). Additional embryos arose during the 6th month on $\mathrm{Km}$ selection but were not saved. Embryos on MS/2 germination medium developed roots and green cotyledons within a few weeks. The first shoots emerged from germinated embryos between 2 and 4 weeks after incubation under increased light intensity (as early as 3 months after bombardment). By 1 year following bombardment, 242 lines with normal shoots and roots were obtained. The plant regeneration efficiency from $\mathrm{Km}^{\mathrm{R}}$ embryos was $54 \%$. The efficiency was similar for each treatment independent of the plasmids used (Table 2). The final conversion rate from embryos to plants, including embryos from control plates, was $55 \%$. No significant differences in plant regeneration were found when the

Table 1 Transient and long-term $\beta$-glucuronidase (GUS) expression following bombardment of 'Chardonnay' embryogenic cell suspensions with plasmid $\mathrm{pBI} 426$

\begin{tabular}{|c|c|c|c|c|c|}
\hline \multirow[t]{2}{*}{ GUS expression } & \multirow[t]{2}{*}{ Incubation (days) ${ }^{\mathrm{a}}$} & \multirow[t]{2}{*}{ Kanamycin (mg/l) } & \multicolumn{3}{|l|}{ Blue spots per plate } \\
\hline & & & Experiment 1 (E1) & Experiment 2 (E2) & Average $\mathrm{E} 1+\mathrm{E} 2^{\mathrm{c}}$ \\
\hline Transient & $\begin{array}{r}2 \\
30\end{array}$ & $\begin{array}{r}0 \\
10\end{array}$ & $\begin{array}{l}6,232 \pm 1,046 \\
1,255 \pm 244\end{array}$ & $\begin{array}{l}9,534 \pm 145 \\
1,482 \pm 165\end{array}$ & $\begin{array}{l}7,883 \pm 1,928 \\
1,369 \pm 224\end{array}$ \\
\hline Long-term & $\begin{array}{l}60 \\
95\end{array}$ & $\begin{array}{l}15 \\
15\end{array}$ & $\begin{array}{c}218 \pm 100 \\
30 \pm 34\end{array}$ & $\begin{array}{r}156 \pm 16 \\
61 \pm 27\end{array}$ & $\begin{array}{r}187 \pm 72 \\
46 \pm 32\end{array}$ \\
\hline
\end{tabular}

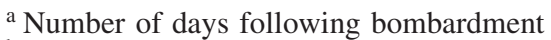

${ }^{\mathrm{b}}$ Mean \pm standard deviation

${ }^{c}$ Ratio of means differs significantly at $P<0.001$; the least significant ratio was 1.258
} 
Table 2 Plant regeneration efficiency from germinated 'Chardonnay' embryos 1 year after bombardment

\begin{tabular}{|c|c|c|c|c|c|c|c|c|c|}
\hline \multirow[t]{2}{*}{ Experiment } & \multirow[t]{2}{*}{ Treatment $^{\mathrm{a}}$} & \multicolumn{2}{|c|}{$\begin{array}{l}\text { No. of } \\
\text { plates }^{b}\end{array}$} & \multirow{2}{*}{$\begin{array}{l}\text { No. of } \\
\text { germinated } \\
\text { embryos }\end{array}$} & \multirow{2}{*}{$\begin{array}{l}\text { No. of } \\
\text { dead em- } \\
\text { bryos }\end{array}$} & \multirow{2}{*}{$\begin{array}{l}\text { No. of } \\
\text { embryos } \\
\text { forming } \\
\text { callus }\end{array}$} & \multirow{2}{*}{$\begin{array}{l}\text { No. of } \\
\text { embryos } \\
\text { developing } \\
\text { cotyledons } \\
\text { but no shoots }\end{array}$} & \multirow{2}{*}{$\begin{array}{l}\text { No. of } \\
\text { regenerated } \\
\text { lines with } \\
\text { shoots and } \\
\text { roots }\end{array}$} & \multirow{2}{*}{$\begin{array}{l}\text { Plant } \\
\text { regeneration } \\
\text { efficiency } \\
(\%)^{\mathrm{c}}\end{array}$} \\
\hline & & $\mathrm{T}$ & $\mathrm{P}$ & & & & & & \\
\hline E1 & $\begin{array}{l}\text { pSAN167/ } \\
\text { pSAN237 }\end{array}$ & 18 & 18 & 78 & 3 & 12 & 23 & 40 & 51.3 \\
\hline E1 & $\begin{array}{l}\text { pSAN168/ } \\
\text { pSAN237 }\end{array}$ & 18 & 17 & 87 & 8 & 16 & 13 & 54 & 62.1 \\
\hline E1 & pSAN237 & 6 & 5 & 30 & 10 & 2 & 3 & 15 & 50.0 \\
\hline E2 & $\begin{array}{l}\text { pSAN315/ } \\
\text { pSAN237 }\end{array}$ & 18 & 18 & 127 & 17 & 10 & 36 & 65 & 51.2 \\
\hline E2 & $\begin{array}{l}\text { pSAN319/ } \\
\text { pSAN237 }\end{array}$ & 18 & 16 & 107 & 11 & 8 & 24 & 56 & 52.3 \\
\hline E2 & $\begin{array}{l}\text { pSAN237 } \\
\text { Total pSAN }\end{array}$ & $\begin{array}{r}6 \\
84\end{array}$ & $\begin{array}{r}4 \\
78\end{array}$ & $\begin{array}{r}18 \\
447\end{array}$ & $\begin{array}{r}5 \\
54\end{array}$ & $\begin{array}{r}0 \\
48\end{array}$ & $\begin{array}{r}1 \\
100\end{array}$ & $\begin{array}{r}12 \\
242\end{array}$ & $\begin{array}{l}66.7 \\
54.1\end{array}$ \\
\hline $\mathrm{E} 1+\mathrm{E} 2$ & pBI426 & 24 & - & - & - & - & - & - & - \\
\hline $\mathrm{E} 1+\mathrm{E} 2$ & $\mathrm{CdNB} / 15 \mathrm{Km}^{\mathrm{e}}$ & 6 & 0 & - & - & - & - & - & - \\
\hline $\mathrm{E} 1+\mathrm{E} 2$ & $\mathrm{CdNB} / 0 \mathrm{Km}^{\mathrm{f}}$ & 6 & 6 & 26 & 4 & 1 & 3 & 18 & 69.2 \\
\hline & Total plates & 120 & 84 & 473 & 58 & 49 & 103 & 260 & 55.0 \\
\hline
\end{tabular}

${ }^{\text {a }}$ Co-bombardment with separate vectors, or single bombardment, or non-bombardment of target cells as indicated in the experimental design

${ }^{\mathrm{b}} T$ indicates total plates per treatment at the beginning and end of the selection period; $P$ indicates positive plates on which at least one embryo emerged

${ }^{c}$ Percentage of germinated embryos that produced plants with roots and shoots

${ }^{\mathrm{d}} \mathrm{pBI}$ 26-bombarded plates were destructively assayed for GUS expression

e $C d N B / 15 \mathrm{Km}$ indicates non-bombarded 'Chardonnay' cell suspension incubated on kanamycin selective MS/2 medium

f $C d N B / 0 \mathrm{Km}$ indicates non-bombarded 'Chardonnay' cell suspension incubated on kanamycin-free MS/2 medium; hundreds of embryos were obtained per plate but only 26 embryos were harvested

Table 3 Co-transformation frequencies of the exogenous genes in regenerated 'Chardonnay' lines by polymerase chain reaction (PCR) and dot blot hybridization (DBH) analyses

\begin{tabular}{|c|c|c|c|c|c|c|c|}
\hline \multirow{2}{*}{$\begin{array}{l}\text { Co-bombardment } \\
\text { treatment }^{\mathrm{a}}\end{array}$} & \multirow{2}{*}{$\begin{array}{l}\text { Number of } \\
\text { selected } \\
\text { 'Chardonnay' } \\
\text { lines }\end{array}$} & \multicolumn{3}{|c|}{ PCR amplification } & \multicolumn{3}{|l|}{$\mathrm{DBH}$} \\
\hline & & \multicolumn{2}{|c|}{$\begin{array}{l}\text { Number of positive } \\
\text { lines }\end{array}$} & $\begin{array}{l}\text { Co-transformation } \\
(\%)^{\mathrm{c}}\end{array}$ & \multicolumn{2}{|c|}{$\begin{array}{l}\text { Number of positive } \\
\text { lines }\end{array}$} & $\begin{array}{l}\text { Co-transformation } \\
(\%)^{\mathrm{c}}\end{array}$ \\
\hline $\begin{array}{l}\text { pSAN237 (npt-II) and } \\
\text { pSAN167 (mag2) }\end{array}$ & 30 & 21 & 16 & 76 & 28 & 15 & 53 \\
\hline $\begin{array}{l}\text { pSAN237 }(n p t-I I) \text { and } \\
\text { pSAN168 }(M S I 99)\end{array}$ & 42 & 32 & 10 & 31 & 41 & 20 & 48 \\
\hline $\begin{array}{l}\text { pSAN237 (npt-II) and } \\
\text { pSAN315 }(P G L)\end{array}$ & 38 & 32 & 14 & 43 & 37 & 21 & 56 \\
\hline $\begin{array}{l}\text { pSAN237 (npt-II) } \text { and } \\
\text { pSAN319 }(\text { mag2) }\end{array}$ & 38 & 28 & 14 & 50 & 38 & 24 & 63 \\
\hline Total & 148 & 113 & 54 & 48 & 144 & 80 & 56 \\
\hline
\end{tabular}

a Plasmids carrying genes involved in each co-bombardment are described in Fig. 1; npt-II neomycin phosphotransferase II gene, mag2 magainin-2 gene, MSI99 synthetic lytic peptide gene, $P G L$ synthetic lytic peptidyl-glycine-leucine gene

${ }^{\mathrm{b}} A M P$ corresponds to the antimicrobial peptide gene from the co-bombardment treatment

${ }^{\mathrm{c}}$ Percentage of $n p t-I I$ positive lines carrying the AMP gene

d pSAN319 harbors mag2 and PGL genes, but only mag2 was assayed via PCR and DBH

chilling treatment was applied. Some germinated embryos (103/473) developed long green cotyledons but shoot formation did not occur by 1 year after bombardment. Over time, other embryos died or developed only callus-like structures (Table 2).

\section{Co-transformation frequency}

The transgenic nature of regenerated plants was initially analyzed by PCR and DBH. A total of 148 lines with well-developed roots and shoots was screened for the presence of exogenous genes to estimate the co-transformation frequency (Table 3). The $\mathrm{Km}$ selection strategy was efficient in both experiments. Most of the analyzed 


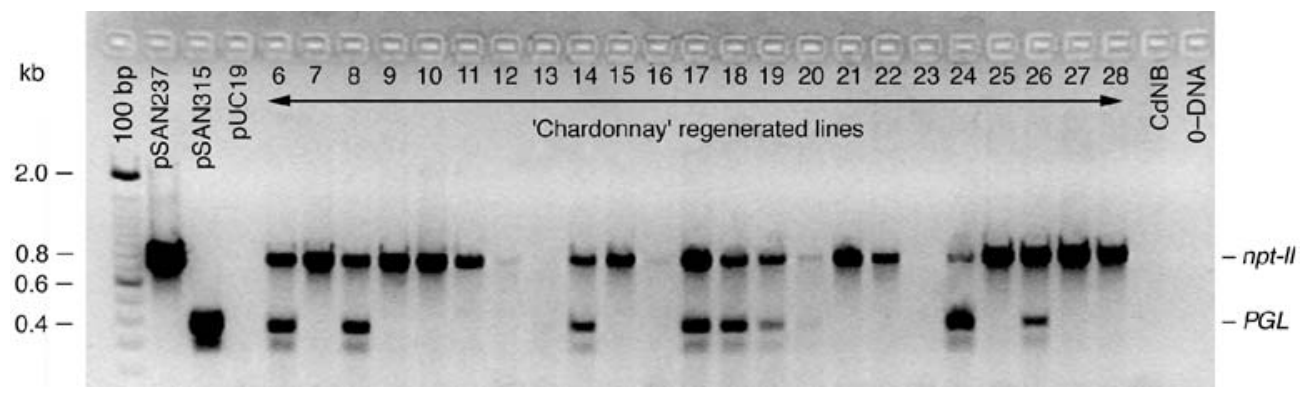

Fig. 2 Multiplex PCR. Lane 1 is a 100-bp ladder (GibcoBRL); lanes 2, 3 and 4 are pSAN237, pSAN315 and pUC19 control vectors, respectively; lanes 6-28 are regenerated plants from cobombardment with pSAN237/pSAN315 constructs; lane 29 is a non-transgenic plant; and lane 30 is a sample without DNA.

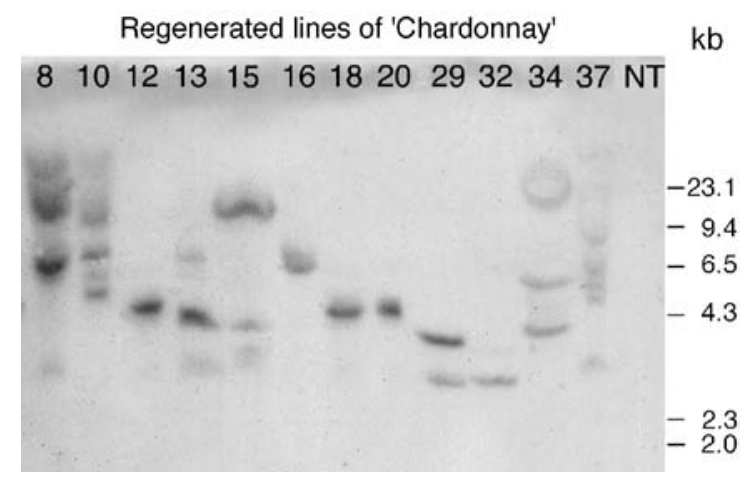

Fig. 3 Southern blot hybridization of 12 transgenic 'Chardonnay' lines carrying the npt-II and MSI99 genes and a non-transgenic (NT) control plant. Genomic DNA was digested with HindIII and hybridized with the npt-II probe which was labeled with digoxigenin. Molecular weight is indicated in thousands of base pairs (kb)

plants were positive for the npt-II gene by either PCR $(113 / 148)$ or DBH $(144 / 148)$ and few escapes were detected. Simultaneous amplification of both foreign genes in transgenic lines was performed by multiplex PCR (Fig. 2). PCR analysis revealed 54 AMP-transgenic lines among 113 carrying the selectable npt-II gene, which corresponded to a co-transformation frequency of $48 \%$ for both unlinked genes. However, the DBH assay showed that from 144 npt-II positive lines, 80 lines were also positive for the AMP gene, corresponding to a $56 \%$ frequency of co-transformation. No PCR or DBH signals for foreign genes were present in control non-transformed plants. All AMP positive lines were also npt-II positive by PCR or DBH. Only five lines were AMP positive by PCR but negative by $\mathrm{DBH}$, which may indicate the presence of chimeras in some regenerated plants.

\section{Transgene integration}

The integration of foreign genes was confirmed by Southern blot analysis. A total of 13 mag2 and 14 MSI99 lines selected from among PCR and/or DBH positive lines were analyzed. Transgene integration is
Samples were amplified at an annealing temperature of $60^{\circ} \mathrm{C}$ with a set of primers specific to the $n p t-I I$ gene and the $P G L$ cassette as shown in Fig. 1. The upper band is a fragment of the npt-II gene and the lower band corresponds to a $P G L$ gene cassette fragment

confirmed when positive signals are obtained from bands of different sizes that represent one cut at the HindIII site in the transgene construct at the $5^{\prime}$ end of the Pubq promoters (Fig. 1) and another cut elsewhere in the plant genome. Positive hybridization signals were obtained with the npt-II probe for all samples and the pSAN237 positive control, but not in the non-transformed 'Chardonnay' negative control (Fig. 3). Positive hybridization signals were obtained in 11 of $13 \mathrm{mag} 2$ and 13 of 14 MSI99 lines using the mag2 and MSI99 probes, respectively (data not shown). No hybridization signals were detected in the non-transformed control. Hybridization signals indicate 1-6 integration events for both $n p t-I I$ and antimicrobial genes. Band numbers and sizes differed among all transgenic lines indicating independent transformation events.

\section{Discussion}

This report focuses on technical improvements to the previous biolistic transformation system for grapevine (Kikkert et al. 1996) leading to highly efficient transformation and regeneration of 'Chardonnay' plants. Technical improvements included: (1) replacing tungsten with gold particles and heating to $180^{\circ} \mathrm{C}$ before coating with DNA; (2) using $10-15 \mathrm{mg} / \mathrm{l} \mathrm{Km}$ for step-wise selection instead of $25-50 \mathrm{mg} / \mathrm{l}$; and (3) incubating cell cultures at $27^{\circ} \mathrm{C}$ for embryo induction during selection instead of $24^{\circ} \mathrm{C}$. As a result, high transient and long-term GUS expression as well as regeneration of transgenic plants was obtained (Table 1 and 2). Using the same pBI426 construct, we report a higher number of blue spots per plate, 7,883 $\pm 1,928$ and $1,369 \pm 224$ at 2 and 30 days after bombardment, respectively, than Hébert et al. (1993) who reported, with 'Chancellor' grape cell suspensions, $1,899 \pm 646$ blue spots per plate 2 days after bombardment and up to 850 blue spots 23 days after bombardment. Other groups failed to obtain efficient transient and stable GUS expression by microprojectile bombardment of grape embryogenic tissues (Franks et al. 1998). In the present study, the same protocol was used in two 
experiments, the only difference being the cluster size of the cell suspension. More embryos were obtained from the co-bombarded plates in E2 than in E1, possibly related to the smaller size and physiological state of the cell clusters at the moment of bombardment. Tissue preculture parameters prior to bombardment have been reported to have a strong influence on stable transformation frequency (Barcelo et al. 1994).

Our combination of selection, germination and regeneration media effectively induced 'Chardonnay' embryo development and plant growth. In a preliminary study, we determined that $15 \mathrm{mg} / \mathrm{l} \mathrm{Km}$ was the minimal concentration for effective elimination of non-transformed embryos from embryogenic cultures (data not shown). To reduce the toxic effects of $\mathrm{Km}$ on grape cells, the concentration was held at $10 \mathrm{mg} / \mathrm{l}$ during the $1 \mathrm{st}$ month and increased thereafter to $15 \mathrm{mg} / \mathrm{l}$. Following bombardment, emerging embryos were considered potential $\mathrm{Km}^{\mathrm{R}}$ transformants because none were observed on control plates. The $\mathrm{Km}$ regime that we report for selection of $\mathrm{Km}^{\mathrm{R}}$ embryos from embryogenic cell suspensions resulted in few escapes over 5 months. Iocco et al. (2001) using embryogenic callus reported non-transgenic escapes for the first embryos harvested on $100 \mathrm{mg} / \mathrm{l} \mathrm{Km}$ medium after Agrobacterium inoculation. The conversion rate of germinated embryos into plants that we obtained for 'Chardonnay' (54\%) was higher than the $10 \%$ reported for this cultivar by Iocco et al. (2001). The conversion rate for other grape cultivars ranged between $10 \%$ and 33\% (Franks et al. 1998; Harst et al. 2000; Iocco et al. 2001), but transformation was performed via Agrobacterium, and higher $\mathrm{Km}$ concentrations (50-100 mg/l) were used for selection. This suggests that high $\mathrm{Km}$ pressure during selection and the use of antibiotics to eradicate Agrobacterium after co-cultivation could decrease grape regeneration. The regeneration efficiency (69\%) obtained here from non-transgenic embryos was similar to the rate (60\%) reported by Jayasankar et al. (1999) for 'Chardonnay' embryos grown on MS basal medium containing 3\% sucrose.

We used finely-divided cell suspensions for bombardment, in which embryos grew primarily from small proembryonic cell clusters rather than larger well-developed embryos. In this way, the chances of obtaining chimeric plants were reduced. The number of lines with DBH positive signals was higher than the number detected via PCR, as expected. A positive PCR signal depended upon complete insertion of the entire fragment into the genomic DNA. Any loss in nucleotides at either primer-annealing site would prevent annealing and amplification would fail. However, with DBH and Southern analyses even partial transgene insertions can still produce a signal by hybridization. Hybridization signals from Southern blots confirmed the hybridization signals from DBH analysis. Only one of 27 lines analyzed was negative by $\mathrm{DBH}$ but positive by Southern analysis. Therefore, we consider that the positive signals for DBH analysis from the 148 plants analyzed are reliable data to support the co-transformation frequency obtained by PCR analysis (Table 3). Extra positive lines detected by DBH and Southern analyses could indicate missing sequences at the primer annealing sites in the transgene.

In this paper, we studied the viability of using cobombardments for multiple-gene transformation of grapevine. Co-transformation with independent genes in separate vectors has been used to facilitate selectable marker removal (Komari et al. 1996). While this may not facilitate improvements to clonally propagated elite cultivars like 'Chardonnay', this strategy has been suggested for rootstock and table grape breeding programs (Scorza et al. 1996). In addition, co-transformation allows transformation projects to proceed without the time consuming need to link different cassettes into the same plasmid. The Agrobacterium-mediated co-transformation frequency for various species was reported to be $100 \%$ for linked genes in a unique T-DNA or for linked T-DNAs in a single binary plasmid, and ranged from $30 \%$ to $85 \%$ for independent T-DNAs in separate binary plasmids (DeBlock and Debrouwer 1991; Komari et al. 1996; Daley et al. 1998; McCormac et al. 2001). The cotransformation frequency via particle bombardment in different plant species was reported to be near $100 \%$ for linked genes and ranged between 33\% and $80 \%$ for unlinked genes (Aragao et al. 1996; Zhong et al. 1996; Dalton et al. 1999; Rasco et al. 2001). Torregrosa and Bouquet (1997), using Agrobacterium, reported a maximal co-transformation efficiency of $16 \%$ in hairy root culture of grapes, but plants were not regenerated. Here, we report for the first time in grapevine a co-transformation frequency in the range of $50 \%$, based on a sample of 148 regenerated transgenic lines (Table 3).

A highly efficient system for the genetic transformation and regeneration of 'Chardonnay' is described. A total of 447 putative transformed embryos were selected from 84 bombarded plates after only 5 months. This represents more than 5 embryos per bombarded plate. In a 1-year period, 242 rooted 'Chardonnay' plants were obtained, which represents a significant advance in regeneration of large numbers of transgenic $V$. vinifera vines with respect to previous reports (Colova-Tsolova et al. 2001; Kikkert et al. 2001). Independent of the construct (5 different bombardments) and the cell suspension (two different sizes) used for transformation, we consistently obtained a regeneration efficiency over $50 \%$ and a co-transformation frequency in the range of $50 \%$. In our experience, biolistics is a reliable and reproducible transformation system. Our improved method should be suitable for other grapevine cultivars, as well as other recalcitrant crops capable of forming regenerable embryogenic cell suspensions. However, the methods of embryogenic culture, embryo induction and plant regeneration should be optimized for each genotype. To our knowledge, this is the first report concerning the integration of natural and synthetic magainin genes in grapes. The expression of AMP genes in these transgenic lines and the tolerance to plant pathogens is still to be determined, and will ultimately require confirmation via field testing. 
Acknowledgements The authors are grateful to Dr. J. Sanford of FMS Foundation and Dr. F. Smith of Sanford Scientific Inc. for the magainin and PGL constructs. Drs. R. Seem and D. Gadoury suggested the use of these constructs. We thank Drs. S. Brown and G. Fermín (Cornell University) for critically reviewing this manuscript and for helpful discussions. This research was supported by Research Grant No. US-2759-96 from BARD, The United States-Israel Binational Agricultural Research and Development Fund, as well as grants from the Cornell Biotechnology Program, the USDA-Viticulture Consortium-East and the Kaplan Fund. J.R. Vidal was supported by a postdoctoral grant from the Spanish Ministry of Education and Science.

\section{References}

Aragao FJL, Barros LMG, Brasileiro ACM, Ribeiro SG, Smith FD, Sanford JC, Faria JC, Rech EL (1996) Inheritance of foreign genes in transgenic bean (Phaseolus vulgaris L.) co-transformed via particle bombardment. Theor Appl Genet 93:142150

Barcelo P, Hagel C, Becker D, Martin A, Loerz H (1994) Transgenic cereal (Tritordeum) plants obtained at high efficiency by microprojectile bombardment of inflorescence tissue. Plant J 5:583-592

Colby SM, Meredith CP (1990) Kanamycin sensitivity of cultured tissues of Vitis. Plant Cell Rep 9:237-240

Colova-Tsolova V, Perl A, Krastanova S, Tsvetkov I, Atanassov A (2001) Genetically engineered grape for disease and stress tolerance. In: Roubelakis-Angelakis KA (ed) Molecular biology and biotechnology of the grapevine. Kluwer, Dordrecht, pp 441-432

Daley M, Kauf VC, Summerfelt KR, Turner JC (1998) Cotransformation with one Agrobacterium tumefaciens strain containing two binary plasmids as a method for producing marker-free transgenic plants. Plant Cell Rep 17:489-496

Dalton SJ, Bettany AJE, Timms E, Morris P (1999) Co-transformed, diploid Lolium perenne (perennial ryegrass), Lolium multiflorum (Italian ryegrass) and Lolium temulentum (darnel) plants produced by microprojectile bombardment. Plant Cell Rep 18:721-726

DeBlock M, Debrouwer D (1991) Two T-DNAs co-transformed into Brassica napus by a double Agrobacterium tumefaciens infection are mainly integrated at the same locus. Theor Appl Genet 82:257-263

Franks T, He DG, Thomas M (1998) Regeneration of transgenic Vitis vinifera L. Sultana plants: genotypic and phenotypic analysis. Mol Breed 4:321-333

Harst M, Bornhoff BA, Zyprian E, Topfer R (2000) Influence of culture technique and genotype on the efficiency of Agrobacterium-mediated transformation of somatic embryos (Vitis vinifera) and their conversion to transgenic plants. Vitis 39:99-102

Hébert D, Kikkert JR, Smith FD, Reisch BI (1993) Optimization of biolistic transformation of embryogenic grape cell suspensions. Plant Cell Rep 12:585-589

Iocco P, Franks T, Thomas MR (2001) Genetic transformation of major wine grape cultivars of Vitis vinifera $\mathrm{L}$. Transgenic Res 10:105-112

Jayasankar S, Gray DJ, Litz RE (1999) High-efficiency somatic embryogenesis and plant regeneration from suspension cultures of grapevine. Plant Cell Rep 18:533-537

Kikkert JR (1993) The biolistic PDS-1000/He device. Plant Cell Tissue Organ Cult 33:221-226

Kikkert JR (1998) Biolistic transformation of plant cells. In: Celis JE (ed) Cell biology: a laboratory handbook, vol 4. Academic, San Diego, pp 157-161

Kikkert JR, Hébert-Soulé D, Wallace PG, Striem MJ, Reisch BI (1996) Transgenic plantlets of 'Chancellor' grapevine (Vitis sp.) from biolistic transformation of embryogenic cell suspensions. Plant Cell Rep 15:311-316
Kikkert JR, Striem MJ, Martens MH, Wallace PG, Reisch BI (1997) Somatic embryogenesis from anthers and ovaries of six grapevine (Vitis sp.) cultivars. In Vitro Cell Dev Biol Plant $33: 314-315$

Kikkert JR, Ali GS, Wallace PG, Reustle GM, Reisch BI (2000) Expression of a fungal chitinase in Vitis vinifera L. 'Merlot' and 'Chardonnay' plants produced by biolistic transformation. Acta Hortic 528:297-303

Kikkert JR, Thomas MR, Reisch BI (2001) Grapevine genetic engineering. In: Roubelakis-Angelakis KA (ed) Molecular biology and biotechnology of the grapevine. Kluwer, Dordrecht, pp 393-410

Komari T, Hiei Y, Saito Y, Murai N, Kumashiro T (1996) Vectors carrying two separate T-DNAs for co-transformation of higher plants mediated by Agrobacterium tumefaciens and segregation of transformants free from selection markers. Plant J 10:165174

Lloyd G, McCown B (1980) Commercially feasible micropropagation of mountain laurel, Kalmia latifolia, by use of shoot-tip culture. Int Plant Prop Soc Proc 30:421-427

Lodhi MA, Ye GN, Weeden NF, Reisch BI (1994) A simple and efficient method for DNA extraction from grapevine cultivars and Vitis species. Plant Mol Biol Rep 12:6-13

Maloy WL, Kari UP (1995) Structure-activity studies on magainins and other host defense peptides. Biopolymers 37:105-122

Martinelli L, Mandolino G (1994) Genetic transformation and regeneration of transgenic plants in grapevine (Vitis rupestris S.). Theor Appl Genet 88:621-628

Mauro MC, Toutain S, Walter B, Pinck L, Otten L, CoutosThevenot P, Deloire A, Barbier P (1995) High efficiency regeneration of grapevine plants transformed with the GFLV coat protein gene. Plant Sci 112:97-106

McCabe DE, Swain WF, Martinelli BJ, Christou P (1988) Stable transformation of soybean (Glycine max) by particle acceleration. Biotechnology 6:923-926

McCormac AC, Fowler MR, Chen DF, Elliott MC (2001) Efficient co-transformation of Nicotiana tabacum by two independent TDNAs, the effect of T-DNA size and implication for genetic separation. Transgenic Res 10:143-155

Murashige T, Skoog F (1962) A revised medium for rapid growth and bio assays with tobacco tissue cultures. Physiol Plant $15: 473-497$

Nakano M, Hoshino Y, Mii M (1994) Regeneration of transgenic plants of grapevine (Vitis vinifera L.) via Agrobacterium rhizogenes-mediated transformation of embryogenic calli. J Exp Bot 45:649-656

Nandadeva YL, Lupi CG, Meyer CS, Devi PS, Potrykus I, Bilang R (1999) Microprojectile-mediated transient and integrative transformation of rice embryogenic suspension cells: effects of osmotic cell conditioning and of the physical configuration of plasmid DNA. Plant Cell Rep 18:500-504

Norris SR, Meyer SE, Callis J (1993) The intron of Arabidopsis thaliana polyubiquitin genes is conserved in location and is a quantitative determinant of chimeric gene expression. Plant Mol Biol 21:895-906

Perl A, Lotan O, Abu-Abied M, Holland D (1996) Establishment of an Agrobacterium-mediated transformation system for grape (Vitis vinifera L.): the role of antioxidants during grapeAgrobacterium interactions. Nat Biotechnol 14:624-628

Rasco GS, Riley A, Cannell M, Barcelo P, Lazzeri PA (2001) Procedures allowing the transformation of a range of European elite wheat (Triticum aestivum L.) varieties via particle bombardment. J Exp Bot 52:865-874

Sanford JC, Smith FD, Russell JA (1993) Optimizing the biolistic process for different biological applications. Methods Enzymol 217:483-509

Sawant SS, Singh PK, Tuli R (2000) Pretreatment of microprojectiles to improve the delivery of DNA in plant transformation. Biotechniques 29:246-248

Scorza R, Cordts JM, Gray DJ, Gonsalves D, Emershad RI, Ramming DW (1996) Producing transgenic 'Thompson Seed- 
less' grape (Vitis vinifera L.) plants. J Am Soc Hortic Sci 121:616-619

Torregrosa L, Bouquet A (1997) Agrobacterium rhizogenes and A. tumefaciens co-transformation to obtain grapevine hairy roots producing the coat protein of grapevine chrome mosaic nepovirus. Plant Cell Tissue Organ Cult 49:53-62

Torregrosa L, Iocco P, Thomas MR (2002a) Influence of Agrobacterium strain, culture medium, and cultivar on the transformation efficiency of Vitis vinifera L. Am J Enol Vitic 53:183-190

Torregrosa L, Verriés C, Tesniére C (2002b) Grapevine (Vitis vinifera $\mathrm{L}$.) promoter analysis by biolistic-mediated transient transformation of cell suspension. Vitis 41:27-32
Vidal JR, Delavault P, Coarer M, Defontaine A (2000) Design of grapevine (Vitis vinifera L.) cultivar-specific SCAR primers for PCR fingerprinting. Theor Appl Genet 101:1194-1201

Yamamoto T, Iketani H, Ieki H, Nishizawa Y, Notsuka K, Hibi T, Hayashi T, Matsuta N (2000) Transgenic grapevine plants expressing a rice chitinase with enhanced resistance to fungal pathogens. Plant Cell Rep 19:639-646

Zhong H, Sun B, Warkentin D, Zhang SB, Wu R, Wu TY, Sticklen MB (1996) The competence of maize shoot meristems for integrative transformation and inherited expression of transgenes. Plant Physiol 110:1097-1107 